\title{
Determinants of Bank Failures in Multiple-Currency Regime in Zimbabwe (2009-2012)
}

\author{
Dzingirai Canicio ${ }^{1} \&$ Katuka Blessing ${ }^{2}$ \\ ${ }^{1}$ Department of Economics, Midlands State University, Gweru, Zimbabwe \\ ${ }^{2}$ Department of Banking \& Finance, Midlands State University, Gweru, Zimbabwe \\ Corresponce: Dzingirai Canicio, Department of Economics, Midlands State University, P Bag 9055, Gweru, \\ Zimbabwe. Tel: 263-773-642-709. E-mail: Dzingiraic@msu.ac.zw or caniciod@yahoo.com
}

Received: May 13, 2014

Accepted: June 22, 2014

Online Published: July 25, 2014

doi:10.5539/ijef.v6n8p229

URL: http://dx.doi.org/10.5539/ijef.v6n8p229

\begin{abstract}
Upsurge in bank failure cases under a more stable currency environment are rare, but the Zimbabwean case raised a lot of questions, which justified the need to deeply investigate sources of bank failures. This is considered an imperative move considering the impact that bank failures pose to stakeholders outside the banking sector such as investors and depositors, the Zimbabwean banking sector itself as well as the entire economy. This study investigated the determinants of bank failures in Zimbabwe under the multicurrency environment. The study employed pooled logit estimator using general to specific logit estimation procedure on fourteen banks by making use of 2009-2012 panel data. Empirical findings indicated that the macroeconomic environment, in particular GDP growth rate, has much influence on bank failure than any other bank fundamental. Among bank fundamentals, liquidity, profitability and capitalisation proved to be prominent bank related determinants of bank failures in their respective order. Findings also suggest that loan-to-deposits ratio (LTD), deposits-to-assets ratio (DTA), gross revenue ratio (GRR), return on assets (ROA), efficiency ratio (EFR), SIZE and GDP growth rate (GDP) variables are negatively correlated to the possibility of banks failing while loan-to-assets (LTA) have positive influence on bank failures. Based on these findings the researcher recommends that RBZ must accentuate liquidity and capital requirements since both liquidity and capital ratios were significant and had higher marginal effects.
\end{abstract}

Keywords: Zimbabwe, bank failures, multiple-currency regime, logit, bank fundamentals

\section{Introduction}

Bank failures remain a problematic phenomenon in Zimbabwe and banks are being identified as failing when they already collapsed. This late identification of failed banks in the economy is then increasing banking sector's fragility considering that the banking sector is the hub for most financial activities in the financial system. Failure of an individual banking institution introduces the possibility of systemic risk and pose contagion effect on the whole financial system which might ultimately result in bank runs and hence long-term panics in the economy. For example, placement of banks under curatorship or judicial liquidation may bring about undesirable as well as unrecoverable losses to stakeholders outside failed banks. This was evidenced by RBZ (2013) when it announced that all funds invested with Interfin Bank Limited will remain frozen during the curatorship period. This engrained panics to stakeholders that were transacting with Interfin and other banking institutions leading to wane in public confidence. Li (2013) supported this view when indicated that an increase in bank failures can affect the overall economic health and the stability of a nation.

Subsequent bank failures brings undesirable consequences to stakeholders outside failed banks and the Zimbabwean economy recorded increases in bank failures with corresponding meltdown in GDP growth rates since 2011 to 2012 as shown in Figure 1. 


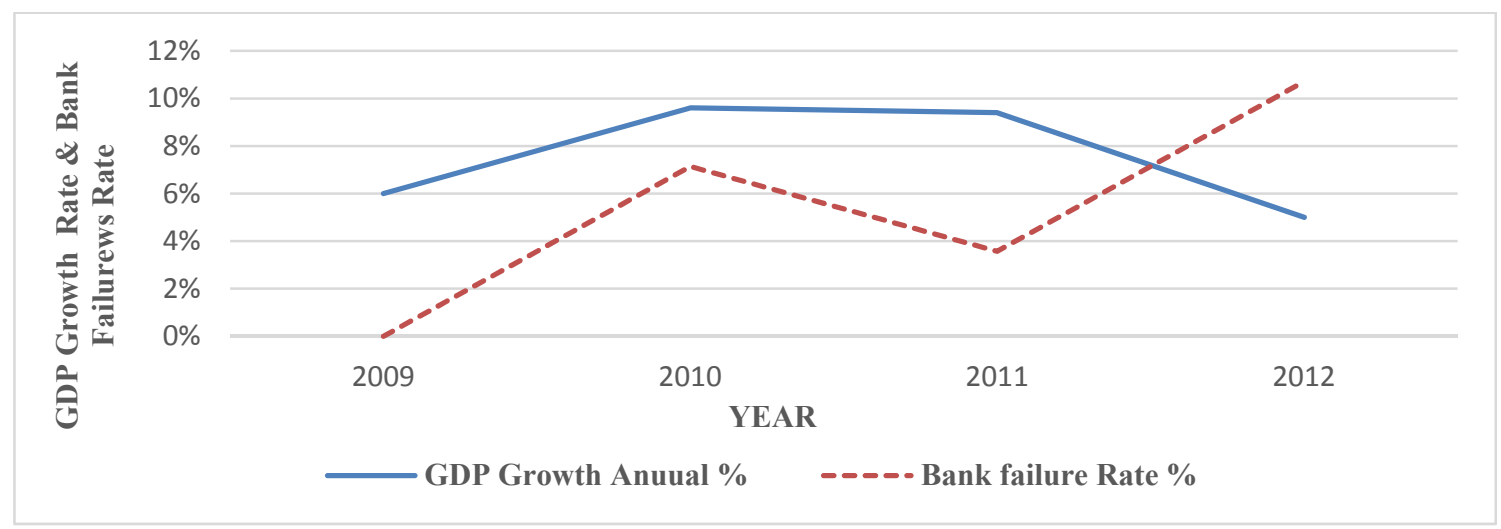

Figure 1. Bank failure rate and GDP growth rate under Multicurrency regime

Source: World Bank (2009-2012).

Figure 1 clearly presents the relationship between GDP growth rate and bank failure rate in Zimbabwe. There is no clarity from the presentation on the relationship that exists between economic performance and bank failures.

Trends reviewed that majority of banks are undercapitalized as shown in figure 2. Figure 2 shows the levels of capitalization between selected compliant and non-compliant banks.

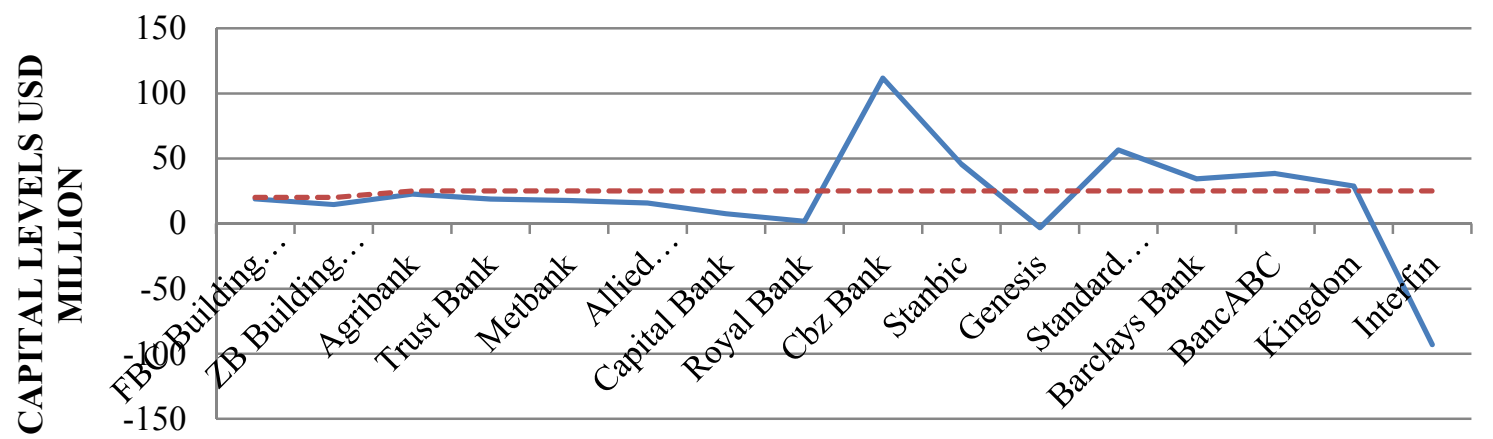

BANKS

Level of capitalisation ( USD million) - - Mandated capitalisation ( USD million)

Figure 2.Capitalisation levels as at 31 December 2012

Source: RBZ (2013).

There is much oscillation in bank capitalization relative to mandated levels as shown in figures 2. Banks are operating below mandated capital levels and gross undercapitalisation will remain a big challenge due to liquidity glitch that is crippling the entire economy. Banks have limited access to off-shore credit lines thus raising the question "how can banks be adequately capitalised or even have excess reserves in such a vacuumed economy characterised by low public confidence, lack of country's own currency and a closed lender of last resort window?"

Zimbabwean financial system had been largely characterized by numerous periods of financial distress as depicted by a plethora of bank failures as well as by severe deterioration of the whole financial system's health. In response to bank collapses that the Zimbabwean economy experienced, so many monetary policy revisions have been done by RBZ to reduce these bank failure cases. However, if Basel accords and resolution policies such as the Troubled Bank Resolution Framework (TBRF) and The Enhanced Troubled and Insolvent Bank Resolution Policy (TIBP) were panacea to bank collapses, "why are bank failures still prevailing in the presence of these revisions?" Why bank failures still prevalent under the MCR which was considered to be the adoption of a more stable currency? How adequate are capital mandates and GDP growth rates in explaining bank failures in light of their behaviors as indicated in figures 1 and 2?" 
Various studies were devoted at researching on the determinants of bank failures but none of the studies was carried out in the Zimbabwean multiple currency context and most of RBZ on-site examination covers qualitative causes of bank failures as enshrined in the Basel accord, with little emphases on the quantitative effects or magnitude of individual causes. Since the commencement of MCR, all banks were subjected to RBZ's rating based on CAMELS framework but all the same bank failures are still alarming. This then raises questions on the adequacy of RBZ's rating system which can be used to identify and monitor weaker banks. Also Mabvure et al. (2012) analysed the sources of non-performing loans but did not dug into their influence on banks' survival equation thus the researcher wishes to cover this gap by identifying the influence of non-performing loan on the possibility of bank failure.

This study will create a better understanding on sources of bank failure along with quantitative effect of each variable and will derive a model based on identified sources. Basing on research findings, regulators and the government shall develop resolution policies based on effects of each cause not on subjective qualitative information associated with each cause. Managers and the other members of staff in the banking sector may be able to interpret, assess and manage their operating activities using the expected bank failure model.

This study seeks to achieve the following objectives:

- To determine whether bank-specific variables are the major determinants of bank failures.

- To highlight any link, if any, between macroeconomic variables and bank failure.

- To develop and estimate a model of bank failures in Zimbabwe.

- To reveal possible ways to deal with failed banks

The study will also test the following hypothesis:

$H_{0:}$ Bank-specific and macroeconomic variables are not the major determinants of bank failure in Zimbabwe.

$H_{l}$ : Bank-specific and macroeconomic variables are the major causes of bank failures in Zimbabwe.

This section introduced the topic and section 2 will review literatures by various authors. Sections 3 and 4 looked at data and methodology and data analysis and results respectively. Lastly, section 5 made conclusions and policy implications.

\section{Literature Review}

The literature review section looks at the theories and empirical studies on determinants of bank failures using various models. There are a limited number of theories on the factors that influences bank failures. The most widely discussed theories are the moral hazard and adverse selection theories which are usually discussed from the insurance perspective. Mishkin and Eakins (2009) are of the idea that adverse selection occurs when one party in a transaction has up to date information than the other party and that moral hazard occurs when one party has an incentive to behave differently once an agreement is made between parties.

Adverse selection occurs at the client selection stage and moral hazard exists after the loan has been disbursed and based on these theories, it is clear that both moral hazard and adverse selection are a result of information asymmetry. This was supported by Laiboni (2012) when cited that asymmetric information creates a problem in the banking sector both before the transaction is closed (adverse selection) and after the transaction has been closed (moral hazard). The author further explained that based on adverse selection theory, lender faces some challenges when attempting to differentiate between good borrowers with good credit risk and bad borrowers with bad credit risk profiles thus they will demand premium to compensate for the risk being assumed. Inability to pinpoint bad from good borrowers makes it more probable for bad borrowers to acquire loans than good borrowers. High interest charges discourages good borrowers from borrowing due to devaluation of good borrowing reputation (credit history) while bad borrowers will be willing to borrow because they will be aware that they should get funds at higher rates due to their credit risk profiles. The problem of moral hazard and adverse section will be exacerbated by lack of credit rating agents.

Selection and disbursement of loans to bad creditors exposes the bank to high defaults since loans would have been given to bad borrowers who have incentives to engage into immoral projects. As a result, lenders end up with loan portfolio comprising almost entirely of bad credit risk (Laiboni, 2012). Loan portfolio constituting high credit risk imply higher levels of non-performing loans, and high levels of non-performing loans infer deterioration in bank assets and hence failure. Copious empirical studies document asset-related problem to be chief causes of bank failure. Oshinsky and Olin (2005), Shaffer (2012) and Babanskiy (2012) were of the opinion that bank failures were more sensitive to non-performing loans. Oshinsky et al. (2005) showed that banks that have riskier assets tend to have a high probability of failure. 
Balasubramanyan (2010) further expressed that non-performing loans lead to huge write downs which erodes the capital base of the bank. This was evidenced by AfrasiaKingdom Bank Zimbabwe that recorded US\$21million of non-performing loans in May 2013 and this misappropriated the survival equation of the institution. High levels of non-performing loans posted by Kingdom led to debacle depletion of its capital base from US\$31 million as at December 2012 to US\$2.4 million as at June 2013.

Shaffer (2012) used the logit estimator in the US and found that bank failures were largely related to non-performing loans (NPL) in 2008 and in 1980s. RBZ (2012) also identified the impact of non-performing loans on loan books. The 2012 on-site examination determined $99.22 \%$ non-performing loans on the total loan book of $\$ 1.52$ million as at 31 May 2012 for Royal Bank Zimbabwe. This non-performing loans level is far much above the prudential benchmark of 5\% stipulated in Basel II (Basel, 2004). Apparently it can be seen that this was the master cause of Royal bank's collapse since loans constitute a larger proportion of bank's assets. All research results showed positive sign associated with this variable, implying that the higher the non-performing loans level the greater the probability of failure.

Mabvure et al. (2012) further dug into the sources of non-performing loans in Zimbabwe. The researchers used a case study research design based on CBZ Bank Ltd backed by some questionnaires. Research found out that the major causes of non-performing in Zimbabwe were natural disasters, government policies and integrity of the borrower. These authors also revealed that failure of banks such as Renaissance Merchant Bank, Interfin Bank and Royal Bank was also due to higher non-performing loans. Non-performing loans could rise further with the ongoing deceleration in economic activity (IMF, 2012). If this is merged with other theories of bank failure, then banks are more likely to continue failing in Zimbabwe.

There is no specific theory that explains the link between bank size and the likelihood of bank failing thus this study explained this concept based on the interconnection between "too big to fail" and moral hazard theories. Too big to fail (TBTF) theory holds the notion that large banks exhibit higher systemic importance in the economy. This being so, authorities endeavor to prevent tumbling of such an institution because its downfall poses disruptions and instabilities to the financial system as well as the entire economy. However preventing TBTF banks from failing is assumed to maintain financial system stability in the short-run (Labonte, 2013). The author explained that rescuing banks is anticipated to result in unstable financial system in the long run because of moral hazard that weakens market discipline.

Labonte (2013) defined moral hazard in the context of TBTF as a theory that if TBTF firms expect that failure will be prevented, they have an incentive to take greater risk than they otherwise would because they are shielded from negative consequences of those risks. However moral hazard problem does not always emanate from the thinking that banks will be rescued if they fail. This was evidenced by episodes of bank failures in Zimbabwe in 2004. None of the failed bank was considered systemically important and their engagement into risky activities was not based on the fact that they will be rescued because the lender of last resort window was closed and government had no funds to bailout banks. Also moral hazard may result from information asymmetry not merely from the availability of bailout programmes. This then abate Labonte hypothesis as the author assumed that moral hazard in bailout context lead to banks to venture into risky activities which lead to failure because they hold a belief that they will be rescued by the government.

Stern and Feldman (2004) further dug into moral hazard and TBTF problems when highlighted that moral hazard problem provides an incentive for firms to grow in order to be perceived as TBTF. In this regard, banks hold the belief that if they permit themselves to grow bigger, they will be considered "too big" thus authorities will not allow them "to fail". However systemic importance of an institution lies not only on its size as traditionally assumed, thus some authors eliminated the use of bank size as a measurement for systemic importance by suggesting new terms. Bernanke (2009) advocated for "too interconnected to fail" and Rajan (2009) is of the idea of "too systemic to fail". New terms were developed due to differences in views of measuring the systemic importance of a bank and that it is not size alone that cause contagion but rather the fact that most activities in certain key market segments flows through those firms (Labonte, 2013). This author was validating such theories as "too interconnected to fail" and "too systemic to fail". The assertion lies along the fact that financial institutions must be considered systemic important based on their linkage to other institutions' activities not on their size alone. Based on contemporary banking theory, banks are assumed to offer transfer and payment systems and failure of an institution, whether large or small in size, which links the majority of market players in the economy may lead to series of failures in other institutions. This means placing value on bank connectedness to other market players rather than basing on its size because there are also banks that are big in size but with little links with other institutions. 
However, most empirical findings identified bank size as significant determinant of bank failures. Researchers such as Borovikova (2000), Rzhevskyy (2003), Bagatiuk and Dzhamalova (2009), Cole and White (2011) and Li (2013) opines that size of the bank is a significant determinant of its failure. These entire authors incorporated this variable in their model but were not in consensus as to whether bank size influences failure positively or negatively. Taran (2012) and Li (2013) remained sceptical of the correlation that exists between bank size and the probability of failure. However all these researchers agreed in their research papers that bank size is proxied by the natural logarithm of bank gross assets.

Bagatiuk and Dzhamalova (2009) employed both linear probability and binary response models such as probit model to investigate financial ratios that better explains bank failures in Russia and Ukraine using financial data from 2002-2008. Their research findings revealed that bank size influence bank failure negatively thus they concluded a negative correlation between bank size and failure. The research results also were also consistent with empirical results of Gonzalez and Kiefer (2006). Gonzalez et al. (2006) concluded that size has negative impact on bank failure, ceteris paribus, and that increase in this variable decreases the risk of bank failure.

The negative sign implies a negative association between bank size and the probability of bank failure. Cole and White (2011) and Li (2013) in their studies carried in USA remained skeptical of the expected sign between bank size and the probability of bank failure. According to Shim (2013), large banks tend to be more diversified when managing capital assets and have easier access to capital markets than smaller banks, implying that small banks are more prone to bank failure than large banks. However Li (2013) cited that large banks might be prone to risky lending activities which may lead to huge losses and failure.

Modern theory of financial intermediation suggest that banks exist to assume two major functions namely liquidity creation and risk transformation. Liquidity creation theory holds the notion that banks can create liquidity on-the balance sheet by financing relatively illiquid assets with relatively liquid liabilities. Kashyap, Rajan and Stein (2002) suggest that banks can also create liquidity off-the balance sheet by loan commitments and similar claims to liquid funds. Risk transformation theory postulates that banks can transform risk through the issuance of riskless deposits to finance risky loans (Ramakrishnan \& Thakor 1984).

The liquidity creation and risk transformation theories usually coincide since there is financing of assets with liabilities in both scenarios. The two theories better explains bank failures when merged with the insolvency theory. Samad (2012) explained the insolvency theory as a theory which holds that banks fail when bank assets value falls short of its value of liabilities. Since assets (loans) that need to be financed are risky under the risk transformation theory, they will be subject to default risk which may ultimately accentuate non-performing loan levels. Samad (2012) supported this by adding on that assets value deteriorate as a result of credit risk emanating from non-performing loans. When the value of these assets falls below bank liabilities, a bank will be said to have failed and this would have been initiated by risk transformation incentives. This was also reinforced by Allen and Gale (2004) when indicated that banks' role as risk transformers and liquidity creators subjects them to risk of failure. The authors further explained that when banks create liquidity, the likelihood of distress increases and severity of losses is execrated as assets are liquidated to meet liquidity demands.

Based on the liquidity creation theory, banks may also raise the likelihood of failure by creating excess liquidity as reviewed by excess liquidity creation hypothesis (ELCH) developed by Fungacova, Ariss and Weill (2013). ELCH was formulated from weak fundamentals hypothesis (WFH) and liquidity shortage hypothesis (LSH). According to ELCH a rise in bank's core liquidity creation activity increases its probability of failure. The hypothesis assumed that bank failure results from banks excessively engaging in its role as liquidity creators based on financial intermediation theory.

WFH covers poor bank fundamentals that impends an impending bank failure. The hypothesis views fragility from assets' risk perspective and is usually proxied by CAMELS elements that signals impending failures for banks with decaying capital ratios, reduced liquidity, deterioration loan quality, and depleted earnings indicating a rising chance of bank failure (Fungacova, Ariss, \& Weill, 2013). LSH focuses on bank's inability to meet liquidity commitments. The theory assumes risk of failure as emanating from liability side of the statement of financial position. Thus, the probability of a bank failure rises with banks inability to timely and fully accommodates deposits redemption. However these authors failed to identify the equilibrium point were ELCH and LSH interacts because ELCH assumes failure from excess liquidity creation standing point and LSH assumes failure from liquidity shortage perspective thus there is need to determine the equilibrium liquidity creation point to hedge impending failure.

However some of the suggested hedging mechanism that Fungacova, Ariss and Weill (2013) proposed on WFH, LSH and ELCH bears financial feedbacks in return and lead to conflicting objectives. For example (LSH) 
deposit insurances, lender of last resort actions and government bailouts efforts creates incentives for moral hazard which WFH attempts to minimize. The major weakness of WFH, LSH, and ELCH is that they hold a notion that failure is a function of liquidity levels and bank fundamentals ignoring such potential pressures from the macroeconomic environment and political interferences.

Arena (2004) empirical findings reviewed that liquidity shocks provoke bank failures due to their inability to honour their short term obligations. Different ratios were used by many researchers with some augmenting each other to produce plausible results. Arena (2008) captured liquidity as a ratio of liquid assets to total liabilities. Arena shows that liquidity ratio have an inverse relationship with the probability of bank crash in East Asia and Latin America during the 1990's. Ercan and Evirgen (2009) investigated the factors that were important in the failure of Turkish banks in 2000-2001 and included liquidity ratios in their analysis banks using a principal component analysis methodology. Finding showed that liquid assets-to-liabilities ratio appears to be significant while the liquid assets-to-total assets ratio does not.

There are a number of macroeconomic and financial linkage theories but the researcher wishes to explain bank failures from creditors' perspective. Generally banks receive funds from bank creditors such as depositor which are then loaned out to borrowers. Bhattacharya and Thakor (1993) indicated that this deposit financing makes banks vulnerable to bank run. According to this author bank runs relates to an individual bank and panic is a simultaneous run on many banks. From this explanation, when individual banks fail to accommodate deposit redemption, they face bank runs which then affect the entire sector leading to panics and finally failure. In broader sense, when depositors (at macro level) suddenly withdraw their funds from an individual institution, they subject that bank to failure and due linkages that an individual institution has with other banks, this will induce subsequent failures (systemic failures).

Bank lending activity must be performed with much savvy in relation customers that an institution is dealing with, maximum volume of loan portfolio that the bank wishes to maintain and finally regulatory benchmarks in order to avoid excessive lending. DeYoung (2003) stipulates that excessive lending contribute to bank failure. This was further supported by Kim and Miner (2007) when they argued that banks that aggressively engage in area outside their expertise are more likely to face higher risk and eventually fail. The downfall of Interfin Merchant bank was related to excessive lending since the bank had loan to deposit ratio of $114.2 \%$. This implied that the institution used more of its depositor's funds to finance loan requests and considering that the institution was a Merchant bank, it had exceeded its maximum limits by greater margins.

Banks do not operate in an isolated tower but rather in an economy where they transact with less ability to influence the outside environment. Mayes and Stremmel (2012) used the logit technique and discrete time analysis in USA to determine the influence of GDP growth rate in predicting bank failures using US banks data from 1992-2012 and research results revealed negative influence of GDP growth rate on bank failures. Negative correlation implied that when economic conditions are good, real GDP will be high and banks are less likely to fail.Researchers such as Lanine and Vennet (2006) neglected macroeconomic variables basing on the fact that all banks will be facing similar conditions. However there is need to incorporate this variable since similar macroeconomic variables such as GDP growth rate can influence banks differently. The bedrock assumption is that banks are affected differently by similar macroeconomic variables. This is the reason why some banks survived the Zimbabwean hyperinflationary environment of 2007-2008. If inflation had exerted similar pressures on all banking institutions, then all banks could have collapsed.

However, there is no clear-cut on whether bank failures influences economic growth or that it is economic growth that influences bank failures. Kupiec and Ramirez (2005) investigated the effect of bank failures on economic growth in the US using VAR and a difference-in-difference methodology. Their results indicated that bank failures reduce subsequent economic growth.

Very few researchers empirically tested the influence of political influence on bank survival equation. RBZ (2006) document that political interference with banks in the areas of lending and recovery played a significant role in bank solvency in 2004.In contrast to RBZ (2006) findings, Borovikova (2000) used a split-population survival time model to Belarusian banks for the period from 1992-1999. Research findings showed that political variables had no significant influence on the probability of failure. The major reason why RBZ (2006) made a conclusion that varies from that of Borovikova (2000) is the difference in levels of political interference on banks by different government in their respective economies. In reiteration, political pressures that Zimbabwean banks face are different from those that were faced by Belarusian banks

Bank failures usually result from capitalization problems and various studies captured capitalisation from different standpoints but the majority relied on the CAMELS framework. Adeyemi (2011) established the main 
determinants responsible for bank failures in Nigeria from 1994-2003. The study observed that inadequate capital among other causes was accountable for bank failures in Nigeria. Gonzalez and Kiefer (2006) employed a duration model to identify main bank specific determinants of bank failures in Colombia. To capture capitalisation, their study used the ratio of total equity to total assets ratio. The study suggested that capitalisation is negatively correlated to probability of bank failure, implying that capitalisation results in a reduction of banks' probability of failure.

Estrella, Park and Peristiani (2000) used a logit model to compare the effectiveness of different types of capital ratios in predicting bank failure in US using 1988-1992 data. The researcher used leverage, gross revenue and risk-weighted ratios. These authors totally neglected the ratio of total equity to assets that has been used by Gonzalez and Kiefer (2006). The fact was that unlike assets, gross revenue includes components associated with off-balance-sheet activities. Moreover, gross revenue contains a crude risk adjustment in that riskier projects are likely to be undertaken only if they provide larger revenues, at least ex ante. Thus, gross revenue may reflect the riskiness of bank assets better than total assets.Li (2013) suggested a negative correlation between this variable and bank failure, which implies that banks with higher gross revenue ratio will be less likely to fail.

Bank failures also emanate from managerial inefficiency. Chinn and Kletzer (2000), Deckle and Kletzer (2001) are of the opinion that the main source of failure rest on bank vulnerabilities to bad management practices reflected in deterioration of their portfolio and capital structure. DeYoung (2003), Wheelock and Wilson (2006) also identified managerial inefficiency as the primary cause for bank failures. RBZ (2006) argued that mismanagement mainly excessive risk-taking is the major determinant of most bank failures in Zimbabwe. RBZ (2006) categorized mismanagement into four folds that are technical mismanagement, cosmetic management, desperate management and fraud. According to RBZ (2006), technical mismanagement involves inadequate policies and procedures, cosmetic encompasses concealing past and current losses to buy time and remain in control while looking and waiting for solution. Clearly cosmetic mismanagement shows central bank's ineffectiveness in terms of on-site examination.

Managerial quality assessment was captured from different angles by many researchers. Ploeg (2010) used the probit, logit, hazard and neural networks model on US banks from 1987-2008. The researcher employed the ratio of total operating expenses to total operating income as a measure of management performance. Researcher findings suggest that banks with high operating expenses relative to operating income are expected to be less efficient and thus have higher probability of failure. Rzhevskyy (2003) indicated that managerial efficiency accounts for bank soundness using the duration model. The bedrock hypothesis was that the higher is managerial efficiency, the less likely that bank will go into bankruptcy.Tatom and Houston (2011) employed the logit and probit model to analyse US banks data for 1988-1994 and 2006-2010 and they explained that DEA is a method of examining production efficiency.

Some researchers incorporated earning ability in their researches. Bongini et al. (2001), Lanine and Vennet (2005) advocate that the usual indicator for earnings is return on assets (ROA) which is the general measure of bank profitability. Lanine and Vennet (2005) used the logit and trait recognition methods in Russia from 1998-2004. Some researchers back this ratio with ROE. However, according to Taran (2012) the effect of the earnings factor is quite ambiguous. From one side, earnings may reflect the efficiency and operational performance and thus have a negative effect on the probability of failure as suggested by Lanine and Vennet (2005). Taran (2012) further explained that from the other side, high profitability may reflect a high level of portfolio risk, and thus has the positive impact on the likelihood of crash as sighted by Jordan et al. (2010). Popruga (2001) utilised the probit cross-section model to identify factors that reduces or raise the probability of becoming bankruptcy in Ukraine. The study employed data for the period of 1995-1996 and findings revealed that, among other indicators, ROA is not key determinant of the soundness of Ukrainian medium-sized bank.

Bouvatier, Brei and Young (2013) examined the determinants of bank failures in the US during the financial crisis of 2008. Their analysis employed limited dependent variable regression techniques such as pooled logit estimator. Research variables were largely based on the CAMELS framework. Findings indicated that banks that failed were characterised by higher loan growth rates, lower levels of capital, higher non-performing loans and higher exposure to mortgage market. Also logit results showed that banks were more likely to fail when they were owned by lower capitalised bank holdings that relied more on funding from money markets and other non-bank subsidiaries.

\section{Data and Methodology}

\subsection{Empirical Model}

Most of the studies relied on constructing financial ratios that proxied the CAMELS elements and used these 
ratios in discriminant and multivariate discriminant analyses, proportional hazard and logit, or multivariate probit econometric models (Kunt, 1989; Gunay et al. 2007; Whalen, 1991). This research will employ a pooled logit model using a general to specific estimation procedure on panel data for fourteen banks and will incorporate a variety of ratios whose greater part of their proportion will also be related to CAMELS components.

The logit model has a binary outcome and is employed to analyze data when the dependent variable is binary and not completely observed. The dependant variable failure (failed or non-failed) is binary such that it equals to one if the bank is a failed one and zero if otherwise. The prediction model is as follows:

$$
F(x)=\exp \left(Z_{i}\right) /\left(1+\exp \left(Z_{i}\right)\right)
$$

Where:

$F(x)$ follows a logistic (cumulative) distribution.

$F(x)$ is a function such that $F: x \rightarrow[0 ; 1]$ and $x$ equals to one if the bank under consideration is a failed one and zero if otherwise.

$\beta_{1}=$ a constant term;

$$
Z i=\beta_{1}+\beta_{2} X_{i}+\varepsilon
$$

$\beta_{2}=$ the vector of coefficients of explanatory variables;

$X_{i}=$ the vector of explanatory variables;

$\varepsilon=$ error term.

Employment of logit model is based on the fact that the dependent variable is a binary or dichotomous variable were the research will be dealing with both failed and non-failed banks. Inclusion of these two sets of banks of different status requires specification of the dependent variable which is failure in the model and this is mostly achieved by employing logit models. Since the dependent variable is binary, it would be inappropriate to use linear probability model (LPM) models because it will produce biased and inconsistent results (Greene, 2008a). The conceptual problem with linear regression with a dichotomous dependent variable stems from the fact that probabilities have maximum and minimum values of 1 and 0 which is a discrete and not a continuous change. Also logit model is not subject to stringent assumptions that are inherent to other models such as MDA, UDA analysis and a catastrophe model of bank failure.

\subsection{Data and Variables}

The study looked at bank failures experienced in Zimbabwe after the adoption of the multi-currency system, that is, from 2009-2012. The research was concentrated between 2009 and 2012 because this is the period where recent bank failures took place after dollarization and the only period with sufficient data necessary for final analysis. Banks under consideration include failed and surviving banks registered as either commercial banks or merchant banks only. This research used panel data that was sourced from financial statements and Deposit Protection Board (DPB). DBP was required to provide data mainly for failed banks since their website were not operational.

Table 1. Explanatory variables in Vector $Z i$

\begin{tabular}{lll}
\hline Variables & Formula and Description & Expected Sign \\
\hline GDP growth rate (GDP) & GDP & - \\
Non-performing loan ratio (NPL) & Non-performing loans / total loans & + \\
Gross revenue ratio (GRR) & Tier 1 capital / (total interest and non-interest income) & - \\
Tier 1 capital ratio (T1CR) & Tier 1 capital / total risk - weighted assets & - \\
Loans to assets ratio (LTA) & Loans / total assets & + \\
Loans to deposit ratio (LTD) & Loans / total deposits & - \\
Deposits to total assets (DTA) & Deposit / total assets & - \\
ROA & Net income / total assets & + \\
Efficiency ratio (EFR) & Total operating expenses / Net operating income & + \\
Size of bank (SIZE) & Ln (total assets) & - \\
\hline
\end{tabular}

\subsubsection{Real GDP Growth Rate (GDP)}

Bank-specific variables alone may be insufficient to explain determinants of bank failure as economic cycles may have impact on bank operations. To capture the macroeconomic effect on bank failure, the researcher will 
include real gross domestic product variable in the model. GDP is usually used to proxy economic growth and was recorded at market price and the researcher expects negative relationship between GDP growth rate and bank failure. The sign implies that when GDP growth rate is increasing, there are fewer chances for banks to fail. GDP is the only macroeconomic variable to be considered in the research because the next best indicator which is inflation is no longer a problem in Zimbabwe. Exchange rate fluctuations cannot be incorporated because Zimbabwe does not own any currency currently.

\subsubsection{Size (SIZE)}

The variable is calculated as the natural logarithm of total assets. It can be argued that strong and healthy banks have large assets volume. The reasoning behind this is based on the fact that large banks hold more assets and have the ability to diversify and reduce their risks, thus small banks are more vulnerable to failure compared to large banks. The variable is expected to have a negative impact on bank failure.

\subsubsection{Asset Quality (NPL)}

This is among CAMEL components and its negligence may imply inadequate research. Almost all researches identified that asset quality is determined by the levels of non-performing loans. Thus in this study, non-performing loans abbreviated by $(N P L)$ was used as a measure of assets quality in both failed and surviving banks. The ratio is calculated by dividing non-performing loans by total loans. The researcher expects this variable positively correlate to bank failure. The general hypothesis is that failed banks loan books constitute higher levels of non-performing loans than surviving banks. Non-performing loans levels for Royal bank were far much higher than for CBZ.

\subsubsection{Capital Ratios}

Bank capital is meant to cushion impending failure thus there exist a significant difference in capitalisation between failed and non-failed banks. In this study, capital adequacy is incorporated in two ways, the tier-one capital ratio and gross revenue ratio.

\subsubsection{Gross Revenue Ratio (GRR)}

The ratio is calculated by dividing tier one capital to total interest and non-interest income.Gross revenue ratio includes off-balance sheet activities (Estrella et al., 2000). This implies that gross revenue ratio reflects the riskiness of bank assets better than total assets. The research expect this ratio to have a negative correlation with bank failure, which suggests that banks with higher gross revenue ratio will be less likely to fail.

\subsubsection{Tier 1 Capital Ratio (T1CR)}

T1CR is the ratio of tier 1 capital to total risk-weighted assets. Tier 1 capital is a bank's core capital and indicates bank's financial strength. Bank that have lower tier 1 capital ratio tends to be weaker than those with higher ratios. Samad (2011) proved that there are significant difference between failed banks and survived banks with respect to tier 1 capital ratio. The researcher expect this variable to have a negative impact on possibility of failure of banks implying that banks with the higher tier 1 capital ratio are less likely to fail.

\subsubsection{Liquidity Ratios}

Liquidity is measured mainly to determine bank's resilience to liquidity risk, thus to hedge against liquidity risk banks must place focus on current sources of liquidity and future cash flows. To capture liquidity more comprehensively, the following ratios will be incorporates.

\subsubsection{Loan-to-Total Assets Ratio (LTA)}

LTA is the ratio of loans to total assets. The liquidity ratio captures the portion of bank's assets that are at risk or indicates what percentage of assets of the bank is burdened with loans. Higher ratios indicate weak liquidity and Wheelock et al. (2000) found that failure was more likely for banks with larger ratios. Shaffer (2012) and Li (2013) found a positive correlation between this ratio and bank failure thus the researcher expects positive sign from the regression results implying that the more loans a bank holds, the higher possibility of failure.

\subsubsection{Loans-to-Deposit Ratio (LTD)}

LTD is the ratio of total loans to total deposits. The ratio measures banks' ability to effectively accommodate deposits redemption by customers. Babanskiy (2010) indicated that too high ratios mean that banks might not have enough liquidity in case of contingency events. The ratio shows how much the bank depends on borrowed funds. The researcher expect this variable to positively correlate to bank failure indicating that banks with high ratios are more likely to fail due to failure settle their liabilities timeously and effectively. 


\subsubsection{Deposits-to-Total Assets Ratio (DTA)}

Is the ratio of total deposits to total assets and the ratio indicates level of investor trust in the bank. DTA ratio also represents a stable source of funding while the bank remains reliable. Higher level of deposits offers banks opportunities to operate at the financial market and meet the problems of liquidity. According to past researches, the ratio should negatively correlate to failure, thus the researcher also expects a negative sign from regression results.

\subsubsection{Earnings Ability (ROA)}

Earning ability of a bank is proxied by return on assets (ROA). It is calculated by dividing net income by total assets. This ratio reflects the efficiency of banks' management on using their assets to generate profit. Higher ROA means greater efficiency in converting assets into net income. Low ROA indicates less efficiency and that the organization is more likely to experience financial difficulty. This variable is expected to have negative impact on the failure of banks.

\subsubsection{Management Quality (EFR)}

The ability and skill of the bank management play a crucial role in the performance and success of the institution. The higher the management competence, the lower is the vulnerability of the bank and the likelihood of making wrong decisions. To capture management quality, the researcher will use efficiency ratio to assess the management quality. This efficiency ratio reflects expenses as a percentage of revenue. The research will assume a positive relationship; the higher the ratio, the more likely is a failure.

\subsection{Diagnostic Test}

The researcher carried out multicollinearity test on explanatory variables. This was done by constructing the correlation matrix that helps to identify variables with high correlation coefficients. Variables that exhibited highest correlation coefficients were not eliminated in data analysis.

\section{Data Analysis and Results}

\subsection{Descriptive Statistics}

Descriptive statistics are summarised such that Table 2 analyses banks according to their statuses as assumed in the model and Table 3 and 4 discusses mean values and variances associated with each bank separately.

Table 2. Descriptive statistics by group

\begin{tabular}{lllllllll}
\hline \multirow{2}{*}{ Variables } & Failed & \multicolumn{7}{c}{ Non-failed } \\
& Mean & Mdn & S.E & Var & Mean & Mdn & S.E & Var \\
\hline LTA & 0.762 & 0.791 & 0.12 & 0.014 & 0.482 & 0.473 & 0.188 & 0.035 \\
LTD & 1.068 & 0.95 & 0.479 & 0.23 & 0.676 & 0.708 & 0.297 & 0.088 \\
DTA & 0.433 & 0.439 & 0.096 & 0.009 & 0.686 & 0.717 & 0.161 & 0.026 \\
GRR & 0.463 & 0.469 & 0.069 & 0.005 & 1.168 & 1.255 & 0.301 & 0.09 \\
T1CR & -0.108 & 0.045 & 0.326 & 0.106 & 0.212 & 0.201 & 0.055 & 0.003 \\
ROA & -0.188 & -0.019 & 0.274 & 0.075 & 0.025 & 0.022 & 0.027 & 0.001 \\
EFR & 3.012 & 1.694 & 2.865 & 8.21 & 0.922 & 0.807 & 0.366 & 0.134 \\
NPL & 0.433 & 0.302 & 0.352 & 0.124 & 0.05 & 0.038 & 0.062 & 0.004 \\
SIZE & 17.427 & 18.206 & 1.725 & 2.975 & 19.063 & 19.19 & 0.866 & 0.75 \\
\hline
\end{tabular}

Table 2 results were constructed from Stata 11 output in appendix B. By comparing banks within the sample, the researcher observed that failed banks had significantly higher LTA mean and median values than surviving banks. Although failed banks had higher LTA mean and median, their variance and standard deviation were significantly lower than that of non-failed banks. Lower variances for failed banks infer that there is greater dispersion in LTA ratio in non-failed banks sample which may indicate higher levels of risk of failure in surviving banks. High variance associated with surviving banks group was largely attributed by individual banks such as Kingdom, Agribank, Tetrad, Stanbic, Metbank and FBC that had high individual variances as depicted by Table 4. Standard deviation also reviewed that non failed banks sample is subject to greater risk of failure. The major reason why failed banks' variance is lower than that of surviving ones is that the average values of each of the failed banks were in a close range as the maximum mean value is 0.8329 for Genesis and the lowest is 0.6364 for Interfin as shown in Table 3 while surviving banks have outliers. Surviving banks had highest mean 
value of 0.65935 for Kingdom and lowest of 0.18975 for Barclays implying greater variability.

Failed banks had also high LTD mean and median values as compared to non-failed banks. From Table 2, it can be discerned that failed banks had high variance in respect of LTD ratio than surviving banks, indicating that they were surely subject to greater risk of failure. In efficiency terms, failed banks had both high EFR mean and variance values than those of surviving banks. Also standard deviation for failed banks is higher relative to non-failed banks indicating greater exposure to failing risk. High mean and variance values were largely attributed by high descriptive statistics values attached to individual banks as depicted in Table 3 and 4 .

Mean, median, standard deviation and variances of NPL for failed banks were high relative to those of surviving banks. High mean, median, standard deviation, and variance figures indicated that failed banks were greatly exposed high risk of failure than non-failed banks. From Table 2, it is apparent that non-failed banks had NPL mean value of approximately $5 \%$ which is in line with international banking standards. However, some individual surviving banks such as Kingdom, Metbank and ZB have higher NPL mean as shown in Table 3 and this might increase their good chance of failing. Higher mean and variances for failed banks are largely emanating from higher values associated with each of the failed banks in Tables 3 and 4 with respect to mean and variance statistics.

In capitalisation terms, failed banks sample had lower GRR and T1CR mean and median values relative to surviving banks inferring that failed banks had less capital to cushion potential risks that were inherent to their operation. Although failed banks had lower mean and median GRR ratio, their variance was lower than that of surviving banks meaning that surviving banks still have a lot of homework to work on in order to reduce their risk of failure as a result of weak capitalisation. More specifically, banks such as Kingdom and Metbank largely contributed to high variances recorded in non-failed banks group raising the need to monitor capitalisation of the two institutions tightly. Failed banks showed lower mean, median and high variance and standard deviation in ROA indicating high levels of failing risk than surviving banking institutions. Although some surviving banks had lower mean ROA, none of them had negative ratio from Table 3 and from the same Table, it is clear that almost all failed banks had negative ROA ratios implying inability to generate economic profits for themselves.

Table 3 presents results that were generated from appendix C. An in-depth analysis in Table 3 indicated that banks such failed banks as Genesis, Interfin and Renaissance had higher loan to assets ratios which could have resulted from aggressive lending approaches which finally stimulated high non-performing loan levels.

Table 3. Mean values by bank

\begin{tabular}{llllllllll}
\hline & LTA & LTD & DTA & GRR & T1CR & ROA & EFR & NPL & SIZE \\
\hline Agribank & 0.553975 & 1.132 & 0.40015 & 1.4528 & 0.19125 & 0.073 & 1.2991 & 0.04648 & 18.041 \\
BancABC & 0.639275 & .741125 & 0.849975 & 1.3207 & 0.20165 & 0.0159 & 0.75198 & 0.03525 & 19.5235 \\
Barclays & .18995 & .250425 & 0.757625 & 1.193075 & 0.25515 & 0.00195 & 0.99465 & 0.0018 & 19.25097 \\
CBZ & .645925 & .8037 & 0.761325 & 1.07325 & 0.281725 & 0.041375 & 0.61693 & 0.0227 & 20.41915 \\
FBC & .471825 & .6352 & .6479 & 1.390125 & 0.220875 & 0.0154 & 0.79478 & 0.0399 & 19.02233 \\
Genesis & .8329 & .680575 & 0.410825 & 0.519775 & -0.35412 & -0.54225 & 6.4524 & 0.65808 & 15.14753 \\
Interfin & .6364 & 1.0485 & 0.5139 & 0.458075 & 0.038875 & -0.00795 & 1.3405 & 0.13708 & 18.7779 \\
Kingdom & .65935 & 0.9414 & 0.645925 & 0.583325 & 0.163075 & 0.02245 & 1.0286 & 0.17888 & 18.719 \\
Metbank & .4304 & 0.6934 & 0.601125 & 1.117825 & 0.2586 & 0.029075 & .81858 & 0.0384 & 18.18545 \\
Renaissance & .816975 & 1.4764 & 0.3754 & 0.410275 & -0.0082 & -0.01468 & 1.2438 & 0.50244 & 18.35672 \\
Stanbic & .356825 & 0.421475 & 0.852075 & 1.163925 & 0.1497 & 0.020675 & 0.7458 & 0.0485 & 19.62055 \\
Stanchart & .290225 & 0.438475 & 0.69845 & 1.184 & 0.198825 & 0.0288 & 0.66827 & 0.0286 & 19.68538 \\
Tetrad & .5974 & 0.84555 & 0.671975 & .981825 & 0.23845 & 0.00305 & 1.5730 & 0.02095 & 18.1882 \\
ZB & .46665 & 0.53015 & 0.658525 & 1.386325 & 0.177875 & 0.0275 & 0.85035 & 0.09338 & 19.04305 \\
\hline
\end{tabular}

Some surviving such as CBZ, BancABC, Agribank and Kingdom bank are also characterised by high loan to assets ratios which are likely to increase their likelihood of default and fragility. Foreign owned banks such as Barclays, Stanchart and Stanbic have lower LTA and NPL ratios. Lower NPL ratio might be due to their reluctance to lend than any of the local banks as indicated by corresponding lower LTA ratios.

Renaissance reported the highest LTD mean followed by Interfin and Agribank. LTD mean values of foreign banks were the lowest in the sample with Barclays having approximately $25 \%$. Surviving banks such as Agribank and Kingdom must curtail their LTD ratios to reduce their risk of failing. Most of the failed banks had 
DTA mean value of less than $50 \%$ indicating low liquidity power and lack of customer confidence. DTA mean value for Agribank is too low and is falling within the range of failed banks. However such big banks as BancABC and Stanbic reported higher DTA mean values which were above $80 \%$ indicating strong bank liquidity and high levels of consumer trust and confidence towards these banking institutions.

Failed banks were also characterised by low capitalisation mean values (GRR and T1CR). Genesis and Renaissance had negative T1CR and GRR mean values. Interfin had positive T1CR but was still heavily undercapitalised considering GRR and T1CR associated with the banking institution. However most of the surviving banks had high GRR mean value except Kingdom bank that is falling within the same range with failed banks. Descriptive statistics from Table 3 indicated that failed banks had low and negative ROA mean values. All surviving banks reported positive ROA means although the values are very low.

Research finding showed that Genesis, Renaissance and Interfin banks had highest EFR and NPL mean values indicating poor managerial and assets quality. Kingdom bank had high NPL mean that was falling within the range of the failed banks. Tetrad and Agribank competed with failed banks in terms of inefficiency; their EFR mean values were within the range with that was reported by failed banks.

Table 4 shows variances for individual banks incorporated in the sample. In terms of LTA variance, FBC showed to be at greater risk due to high variance showing greater dispersion in LTA ratio across the research period. Although failed banks and some surviving banks as CBZ and BancABC had high mean values, these bank set exhibited lower levels of risk than some surviving banks such as Agribank, Tetrad, Stanbic, Metbank, Kingdom and FBC which had relatively high variance compared Renaissance, Interfin and Genesis.

Table 4. Variance values by bank

\begin{tabular}{llllllllll}
\hline & LTA & LTD & DTA & GRR & T1CR & ROA & EFR & NPL & SIZE \\
\hline Agribank & .040957 & .10961 & .010664 & .002186 & .001728 & .001245 & .055125 & .000265 & .322393 \\
BancABC & .008015 & .008698 & .000233 & .002060 & .000042 & .000097 & .009783 & .001709 & .127313 \\
Barclays & .002528 & .003481 & .001253 & .124347 & .001998 & .000043 & .005967 & $1.47 \mathrm{e}-06$ & .048019 \\
CBZ & .010049 & .011429 & .021367 & .054127 & .005159 & .001341 & .001097 & .000769 & .172495 \\
FBC & .046977 & .076747 & .038766 & .015461 & .000360 & .000130 & .000353 & .000174 & .070753 \\
Genesis & .002675 & .009186 & .003888 & .003696 & .198224 & .019355 & 4.93465 & .095558 & .032871 \\
Interfin & .011895 & .122903 & .002206 & .002231 & .017259 & .000038 & .235781 & .007155 & .291756 \\
Kingdom & .020380 & .037282 & .032588 & .100500 & .000575 & .000753 & .091087 & .019025 & .078575 \\
Metbank & .016225 & .00834 & .020590 & .150733 & .004138 & .000441 & .002628 & .000120 & .593011 \\
Renaissance & .006504 & .286714 & .014185 & .003598 & .051738 & .004967 & 1.25771 & .160769 & .071113 \\
Stanbic & .0131324 & .0128152 & .0028542 & .0181626 & .0001323 & 0000869 & .0002724 & .0000123 & .0271165 \\
Stanchart & .009326 & .0229868 & .0170209 & .0396463 & .0010252 & .0004623 & .0073813 & .0001547 & .0353077 \\
Tetrad & .0174581 & .0189978 & .007396 & .0002674 & .0022337 & .0001203 & .6299081 & .0000273 & 1.473028 \\
ZB & .0000386 & .0857645 & .0082578 & .0002779 & .0016428 & .0004158 & .0109358 & .0016835 & .483748 \\
\hline
\end{tabular}

Renaissance and Interfin had the highest LTD variance than any of the banks that were incorporated in the sample. Based on these results, these two failed banks proved that they were really fragile and according to the findings, they were exposed to greater risk of failing. Among surviving banks, Agribank showed greater risk as indicated by high LTD variance in surviving banks sample. This is really worrisome considering that the same banking institution (Agribank) had high LTA mean value in Table 3. Table 4 reveals that FBC and Kingdom were characterised by high levels of risk than any of the failed banks as shown by high DTA variances.

Kingdom and Metbank showed high levels of risk when considering GRR variance and banks such as Genesis and Renaissance proved that they were surely exposed to high levels of risks due to undercapitalisation. Banks such as Kingdom had low capitalisation mean values and high variance showing that the institution still has a lot of revisions to make in order to hedge against impending failure. Genesis and Renaissance indicated high variances in ROA which implies that the two banking institutions were subject to greater risk as a result of failing to effectively generate economic profits for themselves. However most of the surviving banks proved to be less risky although the ROA mean values are very low.

Genesis, Interfin, Renaissance and Tetrad banks are the most inefficiently managed banks and indicated higher levels of risk due to high EFR variances attached to these banks as shown in Table 4. From the same table, it is apparent that Genesis, Interfin and Renaissance had high variances in NPL ratios showing greater exposure to 
the risk of failure. From these findings, the researcher recommends an improvement in managerial efficiency in Tetrad bank.

Based on descriptive statistics in Tables 2, 3 and 4, it can be deduced that banks such as Kingdom and Agribank are at greater risk of failing since most of their mean, median, standard deviations and variance were in the same range with failed banks in most ratios thus much has to be done to align these two banks to other strong banks in surviving banks' sample.

\subsection{Diagnostic Test Results}

Diagnostic test was carried out prior to results estimations and interpretations.

\subsubsection{Multicollinearity Test Results}

Table 5. Correlation matrix of vector explanatory variables

\begin{tabular}{lllllllllll}
\hline & LTA & LTD & DTA & GRR & T1CR & ROA & EFR & NPL & SIZE & GDP \\
\hline LTA & 1.0000 & & & & & & & & & \\
LTD & 0.6586 & 1.0000 & & & & & & & & \\
DTA & -0.342 & -0.542 & 1.0000 & & & & & & & \\
GRR & -0.528 & -0.388 & 0.2813 & 1.0000 & & & & & & \\
T1CR & -0.470 & -0.237 & 0.3913 & 0.5203 & 1.0000 & & & & & \\
ROA & -0.392 & 0.0307 & 0.2988 & 0.4138 & 0.7545 & 1.0000 & & & & \\
EFR & 0.4396 & 0.0619 & -0.37 & -0.396 & -0.841 & -0.883 & 1.0000 & & & \\
NPL & 0.5962 & 0.2437 & -0.377 & -0.567 & -0.803 & -0.700 & 0.7359 & 1.0000 & & \\
SIZE & -0.355 & -0.106 & 0.559 & 0.3440 & 0.6032 & 0.7474 & -0.794 & -0.601 & 1.0000 & \\
GDP & -0.099 & -0.085 & 0.2375 & 0.1407 & 0.2252 & 0.2698 & -0.335 & -0.195 & 0.2713 & 1.0000 \\
\hline
\end{tabular}

The researcher carried out a multicollinearity test by constructing a correlation matrix as indicated in Table 5 . Before the researcher commences explanation of empirical findings, it is vital to indicate that the study should consider the presence of multicollinearity as most of the variables are showing high correlation coefficients in the matrix. However Babanskiy (2012) indicated that multicollinearity pose no threat to research findings since it does not reduce the predictive power or reliability of the model. This being so none of the variables was dropped, thus the researcher employed a do-nothing approach to multicollinearity.

\subsection{Estimation of Regression Results}

Table 6 shows logit regression results, statistical significance of variables incorporated in the models and marginal effects generated from bivariate and multivariate pooled logit regression results. Interpretation and discussion of research results was based on bivariate and multivariate analysis which was made in odds ratios, marginal effects and coefficients context.

Table 6. Pooled and specific to general logit regression results

\begin{tabular}{lllll}
\hline Variables & Bivariate coefficients & Odds ratios & Marginal effects & Multivariate coefficients \\
\hline LTA & $12.89353^{* * *}$ & 397730.2 & .7611487 & $454.327 * * *$ \\
LTD & $2.988742^{* * *}$ & 19.86069 & .4317654 & $-103.284 * * *$ \\
DTA & $-10.75743 * * *$ & .0000213 & -.9950278 & $-68.46534 * * *$ \\
GRR & $-10.25009 * * *$ & .0000354 & -.1273134 & $-103.4679 * * *$ \\
T1CR & $-77.63694 * * *$ & $1.92 \mathrm{e}-34$ & -11.65697 & $25.32403 * * *$ \\
ROA & $-56.08996^{* * *}$ & $4.37 \mathrm{e}-25$ & -14.0132 & $-265.0339 * * *$ \\
EFR & $1.43253^{* *}$ & 4.189284 & .2438601 & $-8.387014^{* * *}$ \\
NPL & $15.15673^{* * *}$ & 3823694 & 2.587835 & $-49.40341^{* * * *}$ \\
SIZE & $-1.066726 * * *$ & .3441332 & -.1492843 & $-25.32048^{* * *}$ \\
GDP & $-42.91765^{* *}$ & $2.30 \mathrm{e}-19$ & -6.358587 & $-3961.7 * * *$ \\
\hline
\end{tabular}

Note. $* *$ Statistically significant at $1 \%$ level; ** Statistically significant at $5 \%$ level; * Statistically significant at $10 \%$ level; LR ratio $=$ 0.0000 . 


\subsection{Interpretation of Regression Results}

All variables coincide with the theoretical expectations in terms of direction of influence in bivariate analysis. However some variables such as LTD, T1CR, EFR and NPL contradicted the theoretical expectations in multivariate model and the model was significant at $1 \%$.

Multivariate logit results showed that liquidity is a bank-specific variable that is more likely to drive bank failures in Zimbabwe because of high coefficients, marginal effects and odds ratios attached to liquidity proxies in the study. In Table 6 liquidity is proxied by LTA, LTD and DTA. Multivariate analysis indicates a positive correlation between LTA ratio and the possibility of failure and findings coincide with theoretical expectations. LTA ratio is positive and significant at $1 \%$ level in both bivariate and multivariate analysis. This was in line with the findings of Babanskiy (2012). Large coefficient suggests that one unit change in LTA has greater influence on bank failure compared to the effects of other bank-specific variables. Based on research findings, a unit increase in LTA ratio is likely to increase the possibility of bank fragility by $0.7611487 \%$.

The significance and positivity of the LTA ratio indicates that banks with higher loans are 397730.2 more likely to fail than those with lower LTA ratios. This was well cited by Wheelock (2000) when revealed that loans are normally the least liquid and most risk assets, meaning that when banks expands their lending activity without a corresponding increase in their capital base, they will be exposing themselves to greater risk of failure since loans are only liquidated when matured. In brief, if banks hoard more loans as a proportion of their assets, they will be increasing the portion of assets that are at risk. Most of recently failed banks such as Genesis and Interfin were characterized by a growing trend of higher loan to assets ratio, thus had a larger proportion of burdened assets. This was supported by higher LTA ratios in Table 2, 3 and 4 (mean, median and variance statistics).

More interestingly, consumer trust and confidence proved to be a relevant determinant of bank failure in Zimbabwe. Among liquidity ratios, DTA proved to be a significant cause of bank failures in Zimbabwe. DTA ratio also represents a stable source of funding and higher level of deposits provides wider opportunities for banks to participate in financial markets and meet liquidity problems. The ratio was negative and significant at $1 \%$ level. According the findings a unit change in DTA will reduce the possibility of failure by $0.9950278 \%$. Odds-ratio indicated that banks with higher DTA ratios are 0.0000213 times less likely to fail as compared to those with lower DTA ratios. This is to say that banks with low DTA have 0.999787 probability of failure compared to those with high DTA.

LTD variable is negative instead of being positive and is significant at $1 \%$ in the multivariate model. Negative sign might be due to increased demand for loans by economic agents with corresponding transitory nature of deposit as a result of low levels of customer confidence as shown by the significance of the DTA variable in the model. Negative sign was in line with the findings of Bagatiuk and Dzhamalova (2009) although these researchers didn't say anything on the meaning of the negative sign. The researcher interpreted LTD findings from loans demand and deposits supply sides. Marginal effects results showed that a unit change in LTD ratio will cause the possibility of bank failure to change by 0.4317654 . Odds-ratios suggest that banking institutions with higher LTD ratios are 19.86069 times more likely to fail as compared to those banks characterised by lower LTD ratios.

Profitability (earnings ability) also proved to affect the possibility of banks failure in the multivariate model as expected. ROA variable was significant at $1 \%$ level and negatively correlate to the possibility of bank failure and this is in line with $\mathrm{Li}$ (2013) findings. According to empirical results, a unit increase in ROA will cause the probability of bank failure to decrease by $14.0132 \%$. The ratio was ranked the second bank specific determinant in the model implying that bank profitability plays a linchpin role in hedging against impending failure if banks are capable of generating more profits. ROA is an indication that more profitable banks are less likely to fail and according multivariate model a unit increase in this ratio will decrease the possibility of failure by 265.0339 . Descriptive statistic revealed that failed banks had lower ROA ratio meaning that it is a relevant determinant of bank failure in Zimbabwe. Failed banks such as Genesis, Interfin and Renaissance had negative ROA ratios in Table 3 in other terms failed banks were less efficient in converting bank assets into income.

Multivariate model suggest that capitalization is also a potential cause of bank failures. Capitalization was proxied by T1CR and GRR in the model. GRR ratio is negative and significant at $1 \%$ as expected and this conformed to Li (2013) and Estrella (2000). Inverse relationship implies that as banks increase one unit of gross revenue, their possibility of failure will decrease by $0.1273134 \%$. In general, GRR significance infers that bank capitalization is more likely to influence bank failure as odds-ratio suggest that banks with lower GRR ratios are 0.9999646 times more likely to fail than those with higher GRR ratios. Also descriptive statistics revealed that failed banks had lower GRR ratios as compared to surviving banks registering the notion that capitalization is a 
relevant determinant of bank failure. Based on Figure 2 in Chapter One most banks are oscillating below the mandated levels and this poses much threat to Zimbabwean banking sector viability.

Banks size is significant at $1 \%$ and is negatively correlated to possibility of failure as expected. Findings are in line with Rzhevskyy (2003). Result revealed that as banks increase in size, probability of failure is reduced by 0.1492843 . Odds-ratio indicated that big banks are 0.3441332 more likely to fail than small banks, thus small banks are much more vulnerable to risk of failure. Descriptive statistics indicated that most of the failed banks were of small size.

Managerial efficiency proxy (EFR) is negative and significant at $1 \%$ in the multivariate model. The empirical findings are not in line with theoretical expectations since the ratio was expected to be positive. However this is in line with the finding of Torna (2010) and the researcher indicated that in the presence of profitability measure, ROA, a negative coefficient for efficiency (EFR) might means that banks perceive that higher costs lead to a better outcome, indicating that perhaps, banks benefit from large expenditures on high quality workers.

The researcher observed that the NPL ratio is positive in bivariate analysis and negative in multivariate analysis but significant at $1 \%$ in both models. Bivariate results imply positive association between non-performing loans and the possibility of failure and this conforms to the findings of Shaffer (2012) and none of the researchers expected a negative sign from regression results. Negative might emanate from reluctance to lend by major banks such as Barclays, Stanbic and Stanchart as indicated by lower NPL and LTA ratios in Table 2 and 3.

Surprisingly, macroeconomic environment proved to influence bank failures than bank fundamentals in the multivariate model. Macroeconomic influence was proxied by GDP in the model and this variable was negative and significant at $1 \%$ in the model as expected. Considering the large coefficient attached to the variables, macroeconomic environment pose much influence to bank failure than any other variables, ceteris paribus. Research findings showed that an increase in GDP growth rate is likely to decrease the possibility of bank failure by 6.358587 , bringing the notion that banks are less likely to fail during periods of high growth in GDP.

\subsection{Bank Failure Prediction Model}

The model incorporated all significant variables and is as follows:

$Z_{i}=454.33 L T A-103.28 L T D-68.47 D T A-103.47 G R R+25.32 T 1 C R-265.03 R O A-8.39 E F R-49.4 N P L-25.32 S I Z E-3961.7 G D P$

Given that we have two banks that have the following ratios:

Table 7. Hypothetical example

\begin{tabular}{lll}
\hline RATIOS & RISKY-BANK A & HEALTHY-BANK B \\
\hline LTA & $78 \%$ & $58 \%$ \\
LTD & $167 \%$ & $42 \%$ \\
DTA & $18 \%$ & $34 \%$ \\
GRR & $13 \%$ & $23 \%$ \\
T1CR & $9 \%$ & $51 \%$ \\
ROA & $-2.1 \%$ & $41 \%$ \\
EFR & 6.4 & 2.1 \\
NPL & $85 \%$ & $5 \%$ \\
\hline
\end{tabular}

Assuming that Bank A (risky) and Bank B (healthy) have same total assets value of $\$ 63884285$ and that GDP growth rate is expected to decline by $10 \%$, according to this research's prediction model, the probability of Bank A failing is $99.99 \%$ and the likelihood of Bank B failing is $4.07 \%$. Based on the results from the above examples, banks must keep the LTA and LTD ratios as low as possible to indicate high liquidity power and reduce the proportion of assets burdened with loans. DTA ratio must be high to indicate high levels of liquidity and customer confidence. From the given example, Bank A had substantially high LTA and LTD ratios. Also banks must endeavour to lower their NPL and EFR ratios to improve their assets and managerial quality respectively. Indeed, NPL ratio must equal or fall below the international benchmark which is $5 \%$ of the total loan book. From model's results, banks must raise DTA, GRR, T1CR and ROA. Raising these ratios imply strengthening bank liquidity, customer confidence, capitalisation and profitability.

\section{Conclusions and Policy Implications}

The study investigated the determinants of bank failures in Zimbabwe under the multicurrency era. Research 
revealed that macroeconomic environment poses much threat to bank stability than any of bank fundamentals. It has been found that changes in GDP growth rate influences the possibility of bank failure by greater magnitude than any of bank-specific factors. Based on magnitudes of each of the proxies of causes of bank failures, liquidity, profitability and capital indicators are reliable influences of bank failures in Zimbabwe. Liquidity was identified as the most prominent bank related cause of failure. This was shown by higher coefficient associated with LTA and DTA ratios. Higher coefficient implied that banks with low DTA and high LTA have weak liquidity power. Also banks with low liquidity thresholds are more likely to fail than those with higher margins. Profitability and capitalization were also identified as relevant determinants of bank failures. These were indicated by high coefficient associated with ROA and GRR ratios. Banks with low capital have higher chance of failure in the multicurrency era relative to those with high capital holdings. Among bank fundamentals, size of the banks also plays a key role in determining an impending failure. According to empirical findings, small banks are more likely to fail than bigger banks. Banks expenditure and revenue generation impacts on the rating of managerial efficiency.

Large banks are more likely to fail regardless of their size due higher levels of loans as a proportion of bank assets. Banks such as CBZ, BancABC and Kingdom have higher LTA ratios which also characterised some failed banks as Genesis and Interfin. Off-balance sheet activities determine the riskiness of bank assets.

Policy implications of this research would be that, although bankers argue for lower capital and liquidity requirements, RBZ must keep on mandating higher requirements to help sustain banking sector resilience and stability. High capital and liquidity mandates could also help identify problem banks early thus help prevent future bank failures that may pose threat to economic and banking sector's health. Liquidity and capital regulations must be kept high as the research statistically proved that most of the failed banks had weak liquidity power and were less capital to cushion potential risks.Also capital requirements must be imposed based on each bank's characteristics rather than the one-size fits-all approach. This stems from the notion that different banks faces different risks at different levels of exposure thus akin capital mandates may understate or overstate some banks total risk.

To stimulate lending, banks must increase their capital holdings to support expansion in their lending business. This should be done by setting aside loan loss provisions and reserves which must be in proportion to loans disbursed. Provisions and reserves must be set by considering individual bank's characteristics such as risk associated with disbursed loans. This tends to be more holistic than making provisions based on orders from RBZ because loan portfolios for different banks are characterised by different risks and returns. From the study, the researcher identified that most of the failed banks had high loan-to-assets ratios and lower capital ratios and high non-performing loans.

To improve bank liquidity and capitalization in the Zimbabwean vacuumed economy, banks must venture into mergers or partnerships with foreign banks since accessing funds offshore is also a challenge due to inability to meet the stringent requirements needed to be met when applying for financial assistance. Higher capital and liquidity positions are regarded as a safety net by bank customers and other investors, thus consumer trust and confidents tend to boost when these stakeholders hold a perception that banks are capitalised and liquid. The notion behind this assertion is that capitalised and liquid banks have depositors funds secured and that they can also meet customers liquidity requirements timeously, thus increasing bank's integrity in the market and hence customer confidence. According to the study, failed banks had lower capital and liquidity ratios and were also characterized by low levels of consumer trust and confidence.

Off-balance sheet items must be incorporated when setting capital level both at bank level and on a regulatory scene by RBZ. Off-balance sheet activities also determine the riskiness of banks assets hence any expansion must be compensated by increasing capital holdings. Failed banks some surviving indicated lower GRR ratios and higher variance showing great exposure to failing risk as a result of unhedged off-balance sheet activities. Banks that must pay attention to improving their GRR include ZB and Kingdom bank.

\section{References}

Adeyemi, B. (2011). Bank failures in Nigeria: A consequence of capital inadequacy, lack of transparency and nonperforming loans? Journal of Banks and Bank systems, 6(1), 99.

Allen, F., \& Douglas, G. (2004). Financial Fragility, Liquidity, and Asset Prices. Journal of the European Economic Association, 2(1), 20-23.

Arena, M. (2008). Bank Failures and Bank Fundamentals: A Comparative Analysis of Latin America and East Asia during the Nineties using Bank Level Data. Journal of Banking and Finance, 32(9), 67-74. 
Babanskiy. (2012). Determinants of bank failures: The case of Russia (pp. 29-32). Umea University. Retrieved from http://www.essays.se

Bagatiuk, O., \& Dzhamalova, V. (2009). The determinants of bank failure: the evidence from Ukraine and Russia (pp. 24-25). School of economics and management: Lund university, seminar 4 June 2001.

Bernanke, B. (2009). Financial Reform to Address Systemic Risk. Speech at the Council on Foreign Relations, Washington, DC, March 10.

Bhattacharya, S., \& Thakor, A. V. (1993). Contemporary banking theory. Journal of Financial Intermediation, 3(2), 26.

Bongini, P., Claessens. S., \& Ferri, G. (2001). The Political Economy of Distress in East Asian Financial Institutions. Journal of Financial Services Research, 19(1), 5-25. http://dx.doi.org/10.1023/A:1011174316191

Borovikova, V. (2000). The Determinants of Bank Failures: The Case of Belarus. EERC MA thesis. Kyiv, 9.

Bouvatier, V., Brei, M., \& Yang, X. (2013). The determinants of bank failures in United States: Revised. BIS Working Paper No. 357, 26.

Chinn, M., \& Kletzer, K. (2000). International Capital Inflows, Domestic Financial Intermediation and Financial Crises Under Imperfect Information. NBER Working Paper, No. 7902. Cambridge, MA: National Bureau of Economic Research.

Cole, R., \& White, L. (2012). Déjà vu all over again: The causes of U.S. commercial bank failures this time around. Journal of Financial Services Research, 42(5), 10-25.

Dekle, R., \& Kletzer, K. (2001). Domestic Bank Regulation and Financial Crises: Theory and Empirical Evidence From East Asia (pp. 65-98). NBER Working Paper, No. 8322. Cambridge, MA: National Bureau of Economic Research.

DeYoung, R. (2003). De novo bank exit. Journal of Money, Credit, and Banking, 35(5), 711-728.

Ercan, H., \& Evirgen, O. (2009). Predicting bank failures in Turkey by Discrete Choice Models. METU Studies in Development, 95-126.

Estrella, A., Park, S., \& Peristiani, S. (2010). Capital Ratios as Predictors of Bank Failure. Federal Reserve Bank of New York Economic Policy Review, 7(July), 33-50.

Fungacova, Z., Ariss, R. T., \& Weill, L. (2013). Does excessive liquidity creation trigger bank failures (pp. 1-12). BOFIT discussion paper, Bank of Finland.

Gonzalez, \& Kiefer. (2006). Bank failure: evidence from the Colombian financial crisis (pp. 16-20). Cornell University.

Greene, W. (2008a). Econometric Analysis (6th ed.). Prentice Hall: Englewood Cliffs.

Kim, J., \& Miner, A. S. (2007). Vicarious Learning from the Failures and Near-Failures of Others: Evidence from the U.S. Commercial Banking Industry. Academy of Management Journal, 50, 680-700.

Kupiec, \& Ramirez, C. (2008). Bank failure and the cost of systemic risk: Evidence from 1900-1930 (pp. 2). Washington, DC: Federal Deposit Insurance Corporation.

Labonte, M. (2013). Systemically important or too big to fail, congressional research service (pp. 6-13). Retrieved from http://www.crs.gov

Laiboni, M. (2012). Asymmetric Information in the Banking Sector: How adverse selection \& moral hazard affect our banking system. rem http://aiboni.wordpress.com/2012/04/09/asymmetric-information-in-the-banking-sector-how-adverse-selec tion-moral-hazard-affect-our-banking-system/

Lanine, G., \& Vennet, R. V. (2006). Failure prediction in the Russian bank sector with logit and trait recognition models. Expert Systems with Applications, 30(3), 463-478. http://dx.doi.org/10.1016/j.eswa.2005.10.014

Li. (2013). What Causes Bank Failures During the Recent Economic Recession (pp. 1-15)? IllinoisWesleyanUniversity. Retrieved from $\mathrm{http} / / \mathrm{www}$,digitalcommons.iwu.edu

Mabvure, T. J., Gwangwava, E., Faitira, M., Mutibvu, C., \& Kamoyo, M. (2012). Non-performing loans in commercial banks: Case of CBZ Bank Ltd Zimbabwe. Journal of Contemporary Research in Business, 4(7), 467. 
Mayes, D. G., \& Stremmel, H. (2012). The effectiveness of capital adequacy measures in predicting bank distress.

Ministry of Finance. (2012). Mid-Year Fiscal Policy Review, July 2012.

Mishkin, F. S., \& Eakins, S. (2009). Financial markets and institutions (6th ed.). Pearson Prentice Hall.

Nikolsko-Rzhevskyy, O. (2003). Bank Bankruptcy in Ukraine: What are the Determinants and can Bank Failure be forecasted (pp. 41-64)? National University of. Kyiv-Mohyla Academy. EERC, MA Thesis. Retrieved from http://www.kse.org

Oshinsky, R., \& Olin, V. (2005). Troubled Banks: Why Don't They All Fail? Federal Deposit Insurance Corporation, Working Paper 2005-03. Retrieved from http://www.fdic.gvt/bank/analytical/working/wp2005/wp

Ploeg, S. V. D. (2010). Bank Default Prediction Models. Erasmus School of Economics MA thesis. Rotterdam.

Rajan, R. G. (2009). Too Systemic to Fail: Consequences, Causes and Potential Remedies. Written statement to the Senate Banking Committee Hearings, May 6.

Reserve Bank of Zimbabwe. (2005). Monetary Policy Statement. Jan 2005 (pp. 177-194). http://www.rbz.co.zw/inc/publications/legaldept/rbzpdfs/MONETARYPOLICYDECEMBER2004.pdf

Reserve Bank of Zimbabwe. (2011). Monetary Policy Statement. July 2011 (p. 17). Retrieved from http://www.rbz.co.zw/pdfs/2011\%20MPS/MPS\%20July\%202011\%2028.07.pdf

Reserve Bank of Zimbabwe. (2012). Monetary Policy Statement. Jul 2012 (pp. 24-25). Retrieved from http://www.rbz.co.zw/pdfs/2012\%20MPS/Mid\%20Term\%20MPS\%20July\%202012.pdf

Reserve Bank of Zimbabwe. (2013). Monetary Policy Statement. January 2013 (pp. 25-35). Retrieved from http://www.rbz.co.zw/pdfs/2013\%20MPS/Jan\%202013\%20MPS.pdf

Reserve Bank of Zimbabwe. (2013). Press statement: Interfin bank limited curatorship and minimum capital $\begin{array}{lllll}\text { requirements for } & \text { banking } & \text { Retrieved } & \text { from }\end{array}$ http://www.rbz.co.zw/pdfs/2013\%20Press\%20Statements/Interfin\%20Bank\%20Limited\%20Curatorship\%2 0and\%20Minimum\%20Capital\%20Requirements\%20for\%20Banking\%20Institutions.pdf

Samad, A. (2012). Credit risk determinants of bank failure: Evidence from US bank failure. International Business Research, 5(9), 10-15. http://dx.doi.org/10.5539/ibr.v5n9p10

Samad, A., \& Glenn, L. M. (2012). Determinants of bank failures? Evidence from US failed banks. International Research Journal of Applied Finance, 3(4), 452.

Shaffer, S. (2012). Bank failure risk: Different now (pp. 3-5)? University of Wyoming, CAMA Working Paper $23 / 2012$.

Shim, J. (2013). Bank capital buffer and portfolio risk: The influence of business cycle and revenue diversification. Journal of Banking and Finance, 37, 761-772.

Stern, G. H., \& Feldman, R. J. (2004). Too Big to Fail: The Hazards of Bank Bailouts (pp. 448-450). Brookings Institution Press. Retrieved from http://www.peterleeson.com/To_Big_to_Fail.pdf

Taran, Y. (2012). What factors can predict that bank will get into trouble during crisis (pp. 4-28)? Evidence from Ukraine, KSE MA thesis.

Tatom, J., \& Houston, R. (2011). Predicting Failure in the Commercial Banking Industry. Networks Financial Institute Working Paper - No. 2011/27.

Torna, G. (2010). Understanding commercial bank failures in the modern banking era. Retrieved from http://www.fma.org/NY/Papers/ModernBanking-GTORNA.pdf

Wheelock, D. C., \& Wilson, P. W. (2000). Why do Bank Disappear? The Determinants of U.S. Bank Failures and Acquisitions. Review of Economics and Statistics, 82, 127-138.

\section{Copyrights}

Copyright for this article is retained by the author(s), with first publication rights granted to the journal.

This is an open-access article distributed under the terms and conditions of the Creative Commons Attribution license (http://creativecommons.org/licenses/by/3.0/). 